\title{
Monte Carlo models for dosimetry in photon beam radiotherapy
}

\section{Doctoral Thesis}

Author(s):

Fix, Michael K.

Publication date:

2001

Permanent link:

https://doi.org/10.3929/ethz-a-004226952

Rights / license:

In Copyright - Non-Commercial Use Permitted 
Diss. ETH Nr. 14399

\title{
Monte Carlo models for dosimetry in photon beam radiotherapy
}

\author{
Dissertation for the degree of \\ DOCTOR OF THE NATURAL SCIENCES \\ of the \\ SWISS FEDERAL INSTITUTE OF TECHNOLOGY \\ ZURICH, SWITZERLAND
}

presented by

Michael K Fix

Dipl. Phys. ETH

born on May 20, 1967

Germany

Accepted on the recommendation of

Prof. Dr. P. Niederer, examiner

Prof. Dr. P. Rüegsegger, co-examiner

Prof. Dr. R. A. Eichler, co-examiner 


\section{Abstract}

The Monte Carlo (MC) technique is recognized as the most accurate method to predict patient dose. Prerequisite for the high accuracy is, however, the precise knowledge of the characteristics of the radiation field, especially in the case of the complex application techniques used in intensity modulated radiotherapy (IMRT). In this work, MC beam models for a Varian Clinac $2300 \mathrm{C} / \mathrm{D}$ with a 6 and $15 \mathrm{MV}$ photon beam have been developed, which are able to describe and analyze the dosimetric situation for IMRT in detail. On the basis of 6 and $15 \mathrm{MV}$ phase space (PS) data, generated with the MC code GEANT, several simple beam models and a multiple source model are investigated.

The full PS information within the geometric radiation field including the head scatter is used to develop simple beam models, wherein the sources are assumed to be point sources. Four different models are investigated which involve different ways to determine the energies and locations of beam particles in the output plane by using a combination of constant or variable spatial fluence distributions with constant or off axis dependent photon energy spectra. Depth dose curves, profiles and relative output factors are calculated with these models and compared with measurements. Good agreement for these comparisons within the geometric radiation field are achieved for the model, which uses a variable spatial particle fluence distribution and off axis dependent photon energy spectra . All other models lead to appreciable deviations between calculated and measured depth doses and/or dose profiles.

For the multiple source model (MSM) the full PS information of the 6 and $15 \mathrm{MV}$ beam is used to characterize 12 sources representing the main components of the beam defining system. By parametrizing the source characteristics and by evaluating the dependence of the parameters on field size, it is possible to extend the validity of the model to rectangular fields without additional precalculated PS data. To validate the MSM, fluences, energy fluences and mean energies determined from original PS data and those reproduced by the MSM are compared. They show very good agreement within $1 \%$ for both energies. In addition, the MC calculated primary photon energy spectra are verified by the corresponding energy spectra derived from transmission 
measurements. Comparisons of MC calculated depth dose curves and profiles, using original and PS data reproduced by the MSM, agree within $1 \%$ and $1 \mathrm{~mm}$ for both energies. Deviations from measured dose distributions are within $1.5 \%$ and $1 \mathrm{~mm}$. Calculated output factors for the $6 \mathrm{MV}$ beam in $10 \mathrm{~cm}$ water depth agree within $1.5 \%$ with experimentally determined data.

In order to characterize a radiation field shaped by an multileaf collimator (MLC) the MSM is supplemented with an accurate model of an 80-leaf dynamic MLC. Using this supplemented MSM, lateral dose distributions are calculated in a water phantom and in a portal water phantom. Two test fields (one for 6 and one for $15 \mathrm{MV}$ ) for the step and shoot technique and two realistic fields (one for 6 and one for $15 \mathrm{MV}$ ) from an IMRT treatment plan delivered with dynamic MLC are investigated. MC calculated dose profiles using the MSM are in excellent agreement with measured data from film dosimetry for all cases studied. To assess possible spectral changes caused by the modulation of beam intensity by an MLC, the energy spectra in five portal planes are calculated for moving slits of different widths. The investigation of a $13 \mathrm{~cm}$ wide field shows an increase in mean photon energy of up to $16 \%$ for the $0.25 \mathrm{~cm}$ slit compared to the open beam for $6 \mathrm{MV}$ and of up to $6 \%$ for $15 \mathrm{MV}$ respectively. Due to transmission, scattered radiation and changes in the energy spectrum the energy fluence increases up to $40 \%$ for decreasing slit widths when the time of direct exposure through the slit is kept constant.

In conclusion, the MSM supplemented with the dynamic MLC has proven to be a powerful tool for investigational and benchmarking purposes or even for IMRT treatment planning. 


\section{Zusammenfassung}

Die Monte Carlo (MC) Technik wird als die genauste Methode zur Dosisvorhersage in Patienten angesehen. Voraussetzung für die hohe Genauigkeit ist allerdings ein präzises Wissen über die Strahlcharakteristik, insbesondere im Falle von komplexen Bestrahlungstechniken, wie sie in der intensitätsmodulierten Radiotherapie (IMRT) verwendet werden. In dieser Arbeit wurden MC Strahlmodelle für einen Varian Clinac 2300 C/D mit einem 6 und 15 MV Photonenstrahl entwickelt, welche in der Lage sind, die dosimetrische Situation in der IMRT detailliert zu beschreiben und zu analysieren. Auf der Basis von Daten der Phasenräume (PS) für 6 und 15 MV, welche mit dem MC Programm GEANT erzeugt wurden, werden verschiedene einfache Strahlmodelle sowie ein Mehrkomponentenmodell untersucht.

Die gesamten PS Informationen innerhalb des geometrischen Strahlungsfeldes, einschliesslich der Streustrahlung des Beschleunigerkopfes, wurde für die Entwicklung von einfachen Stahlmodellen verwendet, bei welchen die Quellen als Punktquellen angenommen werden. Vier verschiedene Modelle werden untersucht, welche jeweils verschiedene Möglichkeiten zur Bestimmung der Energie und des Partikelortes in der Austrittsebene beinhalten, indem konstante oder variable räumliche Fluenzverteilungen mit konstanten oder radial-ortsabhängigen Energiespektren kombiniert werden. Mit diesen Modellen werden Tiefendosiskurven, Profile und relative Output Faktoren berechnet und mit Messungen verglichen. Eine gute Übereinstimmung für diese Vergleiche wird für das Modell erhalten, welches eine variable räumliche Fluenzverteilung des Partikels mit radial-ortsabhängigen Energiespektren verknüpft. Alle anderen Modelle führen zu merklichen Abweichungen zwischen berechneten und gemessenen Tiefendosen und/oder Dosisprofilen.

Für das Mehrkomponentenmodell (MSM) wird die gesamte PS Information für den 6 und 15 MV Strahl für die Beschreibung von 12 Quellen verwendet, welche die Hauptbestandteile des Beschleunigerkopfes sind, um den Strahl zu formen. Durch Parametrisierung der Quellencharakteristiken und durch das Beurteilen der Feldgrössenabhängigkeit der Parameter, kann die Gültigkeit des Modells ohne zusätzliche vorausberechnete PS Daten auf Rechteckfelder erweitert werden. Um das MSM zu validieren 
werden Fluenzen, Energiefluenzen und mittlere Energien, welche aus den originalen und aus den vom MSM reproduzierten PS Daten bestimmt wurden, miteinander verglichen. Dabei zeigt sich eine gute Übereinstimmung innerhalb 1\% für beide Energien. Zusätzlich werden die mit MC berechneten primären Energiespektren der Photonen mit entsprechenden Energiespektren, die aus Transmissionsmessungen rekonstruiert wurden, verifiziert. Vergleiche von MC gerechneten Tiefendosiskurven und Profilen, bei welchen die originalen und die mit dem MSM reproduzierten PS Daten verwendet werden, stimmen für beide Energien innerhalb von $1 \%$ und $1 \mathrm{~mm}$ überein. Abweichungen $\mathrm{zu}$ den Messungen sind innerhalb von 1.5\% und $1 \mathrm{~mm}$. Gerechnete Output Faktoren für den $6 \mathrm{MV}$ Strahl in $10 \mathrm{~cm}$ Wassertiefe stimmen innerhalb von $1.5 \%$ mit experimentell bestimmten Werten überein.

Um ein mit einem Mehrlamellenkollimator (MLC) geformtes Feld charakterisieren zu können, wird das MSM mit einem genauen Modell eines dynamischen 80-Lamellen MLCs erweitert. Mit dem erweiterten MSM werden laterale Dosisverteilungen in einem Wasserphantom und in einem portalen Wasserphantom berechnet. Zwei Testfelder (eines für 6, das andere für $15 \mathrm{MV}$ ) für die step and shoot Technik und zwei realistische Felder (eines für 6, das andere für $15 \mathrm{MV}$ ) aus einem IMRT Bestrahlungsplan mit dynamischem MLC werden untersucht. Für alle untersuchten Situationen sind die mit dem MSM berechneten Dosisprofile in sehr guter Übereinstimmung mit Messungen aus der Filmdosimetrie. Um mögliche spektrale Änderungen zu erfassen, die durch die Modulation des Strahles durch den MLC bedingt sind, werden Energiespektren für dynamische Schlitze verschiedener Breiten in fünf Portalebenen berechnet. Die Untersuchung der Schlitzbestrahlungen in einem $13 \mathrm{~cm}$ breiten Feld zeigt im Vergleich zu einem offenen Strahl einen Anstieg der mittleren Photonenenergie um bis zu $16 \%$ für den $0.25 \mathrm{~cm}$ Schlitz für den $6 \mathrm{MV}$ Strahl und um bis zu $6 \%$ für den $15 \mathrm{MV}$ Strahl. Auf Grund von Transmission, Streustrahlung und Änderungen im Energiespektrum steigt die Energiefluenz für schmaler werdende Schlitzbreiten um bis zu $40 \%$ an, falls die Zeit der direkten Bestrahlung durch den Schlitz hindurch konstant gehalten wird.

Insgesamt zeigt sich, dass das mit dem dynamischen MLC erweiterte MSM ein mächtiges Tool ist, welches für Untersuchungen, zur Bestimmung von Bezugswerten oder sogar für die Bestrahlungsplanung in der IMRT einsetzbar ist. 